Sylwia MROzOwSKA

Uniwersytet Gdański

\title{
Konstytucja europejska wobec deficytu demokratycznego
}

Droblem deficytu demokratycznego w instytucjach europejskich przez wiele lat istnienia Wspólnot Europejskich nie był przedmiotem szczególnego zainteresowania ani urzędników unijnych, ani przywódców państw należących do tej organizacji.

Ożywienie dyskusji politycznej nad kwestią demokratyzacji Unii Europejskiej zapoczątkowało przemówienie niemieckiego ministra spraw zagranicznych Joschki Fischera w Uniwersytecie Humboldta 12 maja 2000 r., w którym przedstawiając swoją wizję przyszłości integracji europejskiej, niemiecki polityk wskazał m.in. na konieczność rozwiązania ,problemu demokracji”,

Nieco wcześniej deficyt demokratyczny stał się przedmiotem wszechstronnej analizy naukowej ${ }^{2}$. W literaturze przedmiotu badano źródła, for-

1 Zob. Tekst przemówienia w języku niemieckim J. Fischer, Vom Staatenverbund zur Foderation - Gedanken uber die Finalitat der Europaischen Integration, 12.05.2000 r., www.auswaertiges-amt.de oraz w języku polskim J. Fischer, Od zwiazku państw do federacji-rozważanie na temat finalizacji integracji europejskiej, „Gazeta Wyborcza”, 25.05.2000 r. Więcej na ten temat pisze m.in. E. Bojenko-Izdebska, Przyszłość Unii Europejskiej - wizja Joschki Fischera, w: Do jakiej Unii zmierzamy. Polityka i gospodarka Unii Europejskiej, red. A. Mania, B. Płonka, Kraków 2001; M. Kempisty, Europa ojczyzn czy ojczyzna Europa, w: B. Fijałkowska, A. Żukowski, Unifikacja i różnicowanie się współczesnej Europy, Warszawa 2002.

2 Zobacz m.in. w: S. S. Andersen, K. A. Eliassen (eds.), The European Union: How Democratic is it?, London 1996; T. Banchoff, M. P. Smith (eds.), Legitymacy and the European Union, Berlin 1998; J. Blondel, R. Sinnot, P. Svensson, People and Parliament in the European union. Participation, Democracy and Legitymacy, Oxford 1999; E. Eriksen, J. Fossum, Democracy in the European Union. Integration through Deliberation?, London 2000; K. Feathersone, Jean Monnet and the democratic deficit in the European Union, „Journal of Common Market Studies” 1994, no. 2; A. Follesdal, P. Koslowski (eds.), Democracy and the European Union, Berlin 1998; K. Nicolaidis, R. Howse (eds.), The federal vision: Legitimacy and levels of governance in the European Union, Oxford 2001; A. Verhoeven, The European Union in Search of 
mułowano definicje deficytu demokratycznego, szukano odpowiedzi na pytania: czym jest Unia Europejska ${ }^{3}$, co to jest demokracja i czy poprawne jest mówienie o demokratycznym nie-państwie ${ }^{4}$.

Wskazywano, z jednej strony, że problem deficytu demokratycznego nie ma w ogóle miejsca ${ }^{5}$ lub jest mało istotny w rozwoju europejskiej integracji politycznej, z drugiej strony, podkreślano jego obecność w Unii Europejskiej $i$ to na wielu płaszczyznach ${ }^{6}$. Pisano, że niedobór demokracji może być przyczyną malejącego poparcia społecznego dla procesów integracji, zaś jego likwidacja jest warunkiem rozwoju UE i nadania jej takiego kształtu, który będzie uzasadniał jej szerszą społeczną akceptację ${ }^{7}$. Negowano również możliwość likwidacji tego zjawiska w strukturach europejskich lub podkreślano, że system instytucjonalny Unii Europejskiej jest na tyle demokratyczny, na ile jest to możliwe $w$ realiach organizacji ponadnarodowej ${ }^{8}$.

Niniejsze opracowanie koncentruje się na tych poglądach, które uznają istnienie deficytu demokratycznego w instytucjach unijnych i postuluja demokratyzację Unii Europejskiej jako szansę na ożywienie procesów in-

a Democratic and Constitutional Theory, London-New York 2002. W literaturze polskiej m.in. w: T. Biernat, ,Deficyt demokracji” w strukturach Unii Europejskiej, w: Demokracja. Teoria. Idee. Instytucje, red. T. Biernat, A. Siwik, Torun 2001; Z. Czachór, Demokracja i instytucjonalizacja wspólnot europejskich, w: Czy kryzys demokracji w Europie?, red. M. Żyromski, Mosina 1995; R. Grzeszczak, Deficyt demokratyczny w strukturach wspólnotowych, „Sprawy Międzynarodowe” 2002, nr 3; K. Klaus, Pojęcie i źródla deficytu demokratycznego w Unii Europejskiej, „Studia Europejskie” 2004, nr 2; E. Popławska (red.), Konstytucja dla rozszerzajacej się Europy, Warszawa 2000; A. Szymański, Globalizacja a problem deficytu demokracji w Unii Europejskiej, „Przegląd Europejski” 2003, nr 2.

3 E. S. Parzymies, Unia Europejska. Nowy typ wspólnoty międzynarodowej, Warszawa 2002.

${ }^{4}$ F. Draus, Integracja europejska a polityka. Szkice krytyczne i prospektywne, Rzeszów 1999.

5 A. Moravcsik, Preference and power in the European Community: A liberal intergovernmental approach, „Journal of Common Market Studies” 1993, no. 4; również A. Moravcsik, Is there a ,Democratic deficit” in World Politics? A framework for Analysis, http://www.Princeton.edu amoravcs/library/framework.pdf(15.05.2005 r.).

6 G. Majone, Europe's democratic deficit: The question of standards, „European Law Journal" 1998, no. 1; R. Kuper, The many democratic deficits of the European Union, w: Political Theory and the European Union Legitymacy, constitutional choice and citizenship, eds. A. Weale, M. Nentwich, London-New York 1998.

${ }^{7}$ T. Banchoff, M. P. Smith, Introduction, w: Legitymacy and the European Union. The contested Polity, London-New York 1999.

${ }^{8}$ R. Grzeszczak, op. cit.; F. Draus, op. cit. 
tegracji politycznej. Zaś celem artykułu jest próba wskazania, czy Traktat Konstytucyjny ma szansę spełnić nadzieję tych, którzy w jego uchwaleniu i przyjęciu przez państwa członkowskie Unii Europejskiej upatrywali najskuteczniejszy sposób likwidacji deficytu demokratycznego.

Wskazuje się, że deficyt demokratyczny jest obecny w Unii Europejskiej od samego początku.

Rozpoczynając budowę zjednoczonej Europy A. Spinelli spierał się z J. Monnetem o wybór drogi integracji. Rozwiązanie pierwszego z nich zakładało utworzenie federacji na początku procesu europejskiego zjednoczenia, pojmując ją jako cel walki konstytucyjnej. Drugie rozwiązanie plasowało władzę federalną na końcu gradualistycznie rozwijanego procesu, podporządkowanego międzyrządowemu mechanizmowi, mobilizującemu narodowe siły zainteresowane w europejskim rozwiązaniu?

Walor strategii Monneta polega na tym, że może ona wciagnąć federalistyczne aktywne siły narodów bez pozwolenia na konstytucyjne reformy. Jej wadą jest to, że nie może być wcielana w życie w sposób demokratyczny, ponieważ wymaga europejskich decyzji, które już nie są kontrolowane przez narodowe parlamenty, a jeszcze nie są kontrolowane przez Parlament Europejski. Stąd ,demokratyczny deficyt” Wspólnoty ${ }^{10}$.

Neofunkcjonaliści wierzyli, że krok po kroku, narodzi się legitymacja pochodząca bezpośrednio od społeczeństw państw członkowskich. Stanie się tak, gdy obywatele poczują dobrobyt płynący z efektywnie działającego aparatu wspólnotowego. Nastąpi transfer lojalności najpierw elit, a potem społeczeństw do nowego centrum - Wspólnot Europejskich ${ }^{11}$.

Tak się nie stało.

W samej Unii Europejskiej zdefiniowano deficyt demokratyczny po raz pierwszy w 1972 r. w Raporcie Vedela ${ }^{12}$. Podkreślono wówczas istnienie przepaści pomiędzy zakresem władzy przekazanej Unii a możliwościami kontroli sprawowania tej władzy przez Parlament Europejski. Wskazano, że wraz z rozwojem i umacnianiem się Wspólnot, parlamenty

9 W. Bokajło, Federalizm - rozwój idei i niektóre teorie, w: Federalizm. Teorie $i$ koncepcje, red. W. Bokajło, Wrocław 1998, s. 110-111.

10 Ibidem. Zobacz też w: K. Tarnawska, Rozwój lobbingu w Unii Europejskiej, „Sprawy Międzynarodowe” 1999, nr 3.

11 E. Hass, Beyond the nation state: Funkctionalism and international organization, Stanford University Press, Stanford 1964, za: K. Klaus, op. cit., s. 55.

12 Report of the Working Party examining the problem of the enlargement of the powers of the European Parliament, Report Vedel, Commission of the European Communities, Brussels 1972. 
narodowe tracą część swoich uprawnień, które jednocześnie nie są przekazywane na poziom europejski ${ }^{13}$.

Zaczęły pojawiać się również postulaty przybliżenia procedur demokratycznych obywatelom. Zauważono, że stopniowa eliminacja deficytu demokratycznego jest koniecznym składnikiem przeciwstawienia się procesowi alienacji obywateli z mechanizmu zarządzania Unią. Przejawem tej alienacji są głosy o „,brukselskiej eurokracji”, która dba tylko o własne interesy i realizuje tylko własne koncepcje $\mathrm{e}^{14}$.

Wśród poglądów postulujących demokratyzację Unii Europejskiej najczęściej pojawiają się postulaty wprowadzenia demokratycznych procedur decyzyjnych lub demokratycznej konstytucji określającej zasady europejskich procesów politycznych.

Likwidacja deficytu parlamentarnego poprzez rozbudowę pełnomocnictw Parlamentu Europejskiego spotkała się ze sceptycyzmem niektórych politologów i prawników. Podkreśla się, że rozbudowa pełnomocnictw Parlamentu Europejskiego nie rozwiązuje problemu demokracji we Wspólnotach, Parlament Europejski nie może bowiem reprezentować tego, co nie istnieje: narodu europejskiego, i nie może odzwierciedlić tego, co (jeszcze) nie istnieje: europejskiej politycznej opinii publicznej, formułującej się poza granicami krajów w kwestii podejmowania decyzji co do polityki europejskiej ${ }^{15}$.

Druga propozycja - konstytucja demokratyczna popierana - wspierana jest argumentacją, że bez uporządkowania na poziomie teoretycznym, a w konsekwencji także w praktyce politycznej tego, co jest uznawane za podstawę ładu politycznego, oraz bez upowszechnienia tak wypracowanego jednolitego wizerunku UE, jedna $z$ istotniejszych barier, jaką jest niemożność racjonalnego wyboru i ustosunkowania się do form organizacyjnych, które nie są dostatecznie rozpoznawalne i zrozumiałe, będzie decydowała o skali deficytu demokracji. Reorganizację systemu prawnego pod kątem likwidacji deficytu demokratycznego należy rozpocząć od powołania konstytucji zawierającej kartę praw zasadniczych ${ }^{16}$.

13 Rezolucja Parlamentu Europejskiego na temat deficytu demokratycznego w Unii Europejskiej, 17 June 1988 (OJC 187/229).

14 R. Ostrihansky, Deficyt legitymacji demokratycznej, w: Parlament Europejski: struktura, zadania, procedury, Kancelaria Sejmu, „Biuletyn Informacyjny” 1995, z. 1.

15 E.-W. Bockeforde, Jakq droga podaża Europa?, w: Europa. Drogi integracji, red. A. Dylus, Warszawa 1999, s. 18; J. Habermas, Obywatelstwo a tożsamość narodowa. Rozważania nad przyszłościq Europy, Warszawa 1993.

16 T. Biernat, op. cit. 
Jaki sposób Traktat Konstytucyjny spełnia oczekiwania tych, którzy w nim upatrywali szansę na likwidację deficytu demokratycznego?

Przyjmując definicję deficytu demokratycznego w instytucjach unijnych za G. Nevolą przyjmujemy, że instytucje wspólnotowe podjęły szereg ważnych decyzji wpływających na życie obywateli poszczególnych państw członkowskich oraz na krajowe procesy polityczne. Równocześnie te same instytucje cierpią na deficyt demokratyczny na wielu poziomach:

1) na poziomie legitymacji związanej z procesami decyzyjnymi, ponieważ nie osiagnięto rzeczywistego powszechnego zaangażowania wszystkich obywateli w proces polityczny;

2) na poziomie legitymacji związanej z przebiegiem procesów decyzyjnych (skomplikowane procedury instytucjonalne, niezgodne z procedurami demokratycznymi, mało przejrzyste, odległe od obywateli;

3) na poziomie legitymacji związanej z rezultatem procesów decyzyjnych (niewielkie uprawnienia i korzyści rzeczywiście nabyte przez ogół, mała skuteczność regulacyjna w ważnych sektorach).

Istotne jest zwrócenie uwagi na demokratyczne treści Traktatu Konstytucyjnego oraz na sposób uchwalania i ratyfikacji Traktatu.

Konwentowi ${ }^{17}$ powierzono zadanie sformułowania odpowiedzi m.in. na pytanie: jak przybliżyć obywatelom problematykę europejską i działanie europejskich instytucji ${ }^{18}$ ?

Po ukonstytuowaniu się Konwentu Europejskiego 28 lutego 2002 r. powołano do życia ,aktywne społeczeństwo obywatelskie”. Tego samego dnia utworzono forum internetowe o tym samym tytule $\mathrm{z}$ zamiarem wciagnięcia obywateli Europy do dyskusji nad przyszłością Europy ${ }^{19}$.

Wydaje się jednak, że sam nośnik - internet - wyklucza niektóre osoby $\mathrm{z}$ tego procesu.

Za nie w pełni demokratyczny uznawany jest sposób ratyfikacji Traktatu Konstytucyjnego. Ponieważ nie wszędzie Traktat zostanie poddany narodowemu referendum wskazuje się, że nie będzie mógł być uznawany za wysoce demokratyczną formę „umowy społecznej” pomiędzy naroda-

17 Zobacz też w: K. Bachmann, Konwent o przyszłości Europy. Demokracja deliberatywna jako metoda legitymizacji władzy $w$ wielopłaszczyznowym systemie politycznym, Wrocław 2004.

18 A. Kraińska, Wkład Parlamentu Europejskiego $w$ refleksję nad Europejska Konstytucja. Studium na przykładzie udziału Parlamentu Europejskiego w pracach Konwentu Europejskiego, „Przegląd Prawa Europejskiego” 2004, nr 3.

19 M. Kuhn, Czt Europa idzie droga ku społeczeństwu obywatelskiemu?, „Europe Infos" 2005, nr 70. 
mi Europy. Forma traktatowa uniemożliwia też przyjęcie „konstytucji unijnej" większością głosów, co jest rozwiązaniem typowym w przypadku konstytucji narodowych ${ }^{20}$.

Tytuł VI części pierwszej Traktatu Konstytucyjnego ${ }^{21}$ precyzuje zasady udziału obywateli w funkcjonowaniu Unii Europejskiej. „Zasada demokratycznej równości” zobowiązuje wszystkie instytucje, organy, urzędy i agencje Unii do traktowania obywateli z jednakową uwagą (art. I-45 TK). Kolejna - „zasada demokracji przedstawicielskiej”, ma stanowić podstawę funkcjonowania Unii (art. I-46 ust. 1 TK). Konkretyzujące ją postanowienia wskazują na źródła władzy instytucji Unii. Zgodnie z nimi obywatele są na poziomie Unii bezpośrednio reprezentowani w Parlamencie Europejskim, a państwa członkowskie są w Radzie Europejskiej i Radzie reprezentowane odpowiednio przez szefów państw i rządów, które z kolei odpowiadają ,zgodnie z zasadami demokracji” przed parlamentami narodowymi lub przed swoimi obywatelami (ust. 2). Realizując postulat przybliżenia działań Unii do obywatela Traktat deklaruje, że „każdy obywatel ma prawo uczestniczyć w życiu demokratycznym Unii”, a „decyzje są podejmowane w sposób jak najbardziej otwarty i zbliżony do obywatela" (ust. 3). Pewną wskazówką dla obywateli wyrażających wolę uczestniczenia w ,życiu demokratycznym Unii” są postanowienia ust. 4 (oraz art. II-72 ust. 2), który stanowi, że to właśnie partie polityczne (na poziomie europejskim) przyczyniają się do kształtowania „europejskiej świadomości politycznej i wyrażania woli obywateli Unii”. Zasada „demokracji uczestniczącej" zobowiązuje instytucje Unii do umożliwienia obywatelom i ,stowarzyszeniom przedstawicielskim” wypowiadania się i publicznej wymiany poglądów we wszystkich dziedzinach działania Unii oraz do utrzymywania z nimi otwartego, przejrzystego i regularnego dialogu (art. 47 ust. 1 i 2 TK). W szczególności Komisja Europejska będzie zobowiązana do prowadzenia szerokich konsultacji z zainteresowa-

20 A. Bałban, Traktat konstytucyjny Unii Europejskiej a tradycje konstytucyjne państw członkowskich, w: Konstytucja dla Europy. Przyszły fundament Unii Europejskiej, red. S. Dudzik, Zakamycze 2005; M. Witkowska, Co warto wiedzieć o konstytucji Unii Europejskiej, Warszawa 2004.

21 Zobacz też w: J. Barcz, Przewodnik po Traktacie Konstytucyjnym, Warszawa 2005; J. Barcz (red.), Przyszły traktat Konstytucyjny. Zagadnienia prawno-polityczne, instytucjonalne i proces decyzyjny w UE, Warszawa 2004; J. Barcz, C. Mik, A. Nowak-Far, Ocena Traktatu Konstytucyjnego: wyzwania dla Polski, Warszawa 2003; S. Dudzik, Konstytucja dla Europy. Przyszły fundament Unii Europejskiej, Zakamycze 2005; M. Witkowska, Co warto wiedzieć o konstytucji Unii Europejskiej, Warszawa 2004. 
nymi stronami „,W celu zapewnienia spójności i przejrzystości działań Unii" (ust. 3). Całkowicie nowym rozwiązaniem jest wprowadzenie do systemu decyzyjnego przyszłej Unii prawa inicjatywy obywatelskiej. Co najmniej milion obywateli Unii, pochodzących ,ze znacznej liczby państw członkowskich" będzie mógł wezwać Komisję Europejską do przedłożenia inicjatywy legislacyjnej w sprawie, w odniesieniu do której, zdaniem obywateli, wykonanie TK wymaga aktu prawnego Unii ${ }^{22}$.

Do demokratycznych postanowień traktatowych zaliczono również następujące regulacje:

1) umacniające dialog społeczny i współpracę z partnerami społecznymi;

2) regulujące status i kompetencje Europejskiego Rzecznika Praw Obywatelskich;

3) umacniające przejrzystość działania instytucji organów i jednostek organizacyjnych Unii, w szczególności wspierające dobre rządzenie, ustanawiające jawność procesu legislacyjnego w Parlamencie Europejskim i w Radzie oraz prawo dostępu obywateli Unii do jej dokumentów;

4) regulujące zasady ochrony danych osobowych;

5) ustanawiające zasady współpracy z kościołami i organizacjami niewyznaniowymi.

Wszystkie te regulacje mają znaczenie porządkujące, co oznacza, że zasadniczo nie tworzą nowego stanu prawnego.

6) zasady współpracy z partnerami społecznymi, kościołami, organizacjami wyznaniowymi, a także postanowienia dotyczące przejrzystości działań Unii, Rzecznika Praw Obywatelskich Unii oraz ochrony danych osobowych.

Deklaracja 23 do Traktatu Nicejskiego (I Raport Neapolitano) postuluje demokratyzację Unii poprzez przyznanie większych kompetencji Parlamentowi Europejskiemu oraz wzmocnienie parlamentów narodowych na poziomie unijnym w stosunku do rządów ${ }^{23}$.

Również w Raporcie „Rada Europejska z Laeken i przyszłość Unii Europejskiej”, który precyzuje m.in. postulaty Parlamentu Europejskiego dotyczące rewizji traktatów czytamy, że Parlament Europejski opowiada się m.in. za eliminacją deficytu demokratycznego charakteryzującego Unię Gospodarczą i Walutową.

22 Zob. C. Herma, Najważniejsze postanowienia systemowe Traktatu Konstytucyjnego Unii Europejskiej (część I), „Biuletyn UKIE” 2004, nr 14.

23 G. Neapolitano, Raport A5-0427/2002, Rezolucja Parlamentu Europejskiego z $14.01 .03 \mathrm{r}$. 


\section{Parlament Europejski}

PE startował z bardzo niskiego poziomu. Przez długie lata spełniał funkcje swoistego decorum w systemie instytucjonalnym Wspólnoty Europejskiej i zdecydowanie sytuował się na drugim planie. Jego kompetencje były nadzwyczaj skromne, sprowadzały się niemal wyłącznie do wyrażania opinii, doradzania i oceniania bez jakichkolwiek możliwości stanowiących. PE z niebywałą konsekwencją dążył jednak do podniesienia swojej rangi i zwiększenie zakresu przysługujących mu uprawnień. Jego historia to wznoszenie się na coraz wyższy poziom kompetencyjny oraz mozolne przełamywanie rozmaitych barier i ograniczeńn ${ }^{24}$.

W TK następuje wzmocnienie roli Parlamentu Europejskiego. W świetle TK PE zyskuje kompetencje stanowiące w sprawach objętych dzisiaj III filarem. Jeżeli Rada Europejska i Parlament Europejski nie moga osiągnąć porozumienia w sprawie projektowanego aktu, akt ten nie zostaje przyjęty (art. I-34 TK).

TK powtarza istniejące kompetencje Parlamentu Europejskiego (tworzenie prawa we współpracy z Rada, udział w przyjmowaniu budżetu Unii, funkcje kontrolne i konsultacyjne, obsadzanie lub udział w obsadzaniu określonych stanowisk, w tym Przewodniczącego Komisji Europejskiej).

Szereg przepisów umacnia pozycję Parlamentu w systemie instytucjonalnym, w tym w procedurze legislacyjnej. Następuje to poprzez objęcie około 50-ciu nowych obszarów zwykłą procedurą legislacyjną, w której pozycja Parlamentu, jako legislatora jest praktycznie zrównana z pozycją Rady.

Pomimo tych uregulowań częste są głosy, iż Konstytucja jedynie częściowo realizuje postulat zwiększenia demokratycznej legitymacji i przejrzystości instytucji unijnych. Bowiem zwiększając kompetencje Parlamentu wprowadza jednocześnie rozwiązania wzmacniające element międzyrządowy w Unii. Kompetencje przyznane Radzie Europejskiej powoduja, że punkt ciężkości rządu europejskiego przesunął się w kierunku Rady Europejskiej.

Ponadto wskazuje się, że Konstytucja określając zasady prawa wyborczego obowiązującego w wyborach do Parlamentu w dalszym ciagu nie uwzględnia jednej z fundamentalnych zasad demokratycznego prawa wyborczego tj. zasady równości w znaczeniu materialnym, tj. wymóg, by każdy głos posiadał taką samą siłę.

24 M. Bankowicz, System instytucjonalny Unii Europejskiej i perspektywy jego przebudowy, w: A. Mania, B. Płonka, op. cit., s. 75. 
Dla parlamentów narodowych podstawowe znaczenie posiadają postanowienia dwóch protokołów: pierwszy w sprawie roli parlamentów narodowych w UE oraz drugi - w sprawie stosowania zasad pomocniczości i proporcjonalności.

Pierwszy z nich modyfikuje postanowienia protokołu o tym samym znaczeniu dołączonego do Traktatu z Amsterdamu.

Po pierwsze rozszerzony i zmieniony zostaje mechanizm informowania parlamentów narodowych; ustalono system monitorowania przestrzegania zasady subsydiarności przy formułowaniu projektów aktów prawnych; ustanowiono tzw. procedurę pomostową, która oznacza obowiązek informowania parlamentów narodowych o zamiarze Rady Europejskiej zmiany procedury legislacyjnej oraz rozszerzono mechanizmy współpracy międzyparlamentarnej.

Protokół w sprawie stosowania zasady proporcjonalności i pomocniczości ustanawia mechanizm monitorowania przez parlamenty narodowe przestrzegania zasady subsydiarności ${ }^{25}$.

Procedura pomostowa sprawia, że nawet sprzeciw ze strony jednego parlamentu narodowego może wstrzymać decyzję europejską Rady Europejskiej umożliwiając podejmowanie decyzji większością kwalifikowaną w miejsce jednomyślnego stanowienia Rady oraz zastępowania procedury ustawodawczej procedurą zwykłą.

Do pozostałych postanowień TK, które wzmacniają rolę parlamentów narodowych zalicza się:

- artykuł dotyczący klauzuli elastyczności, który przewiduje udział parlamentów narodowych w kontroli środków podejmowanych przez Unię, które nie mają jednoznacznej podstawy w postanowieniach TK, ale są niezbędne do osiągnięcia jednego z celów Unii;

- wspomniana zasada demokracji przedstawicielskiej ma zwracać uwage na udział parlamentów narodowych w zapewnieniu Unii legitymacji demokratycznej, ale jednocześnie podkreśla znaczenie efektywności mechanizmów oddziaływania parlamentów narodowych na własny rząd;

- ponadto procedura przyjęcia do UE nowego państwa zobowiązuje do poinformowania parlamentów narodowych państw członkowskich o wpłynięciu wniosku w sprawie uzyskania członkostwa; włączenie parlamentów narodowych w regulacje dotyczące Przestrzeni Wolności Bezpieczeństwa i Sprawiedliwości; utrzymanie obowiązku poinformo-

25 Zobacz więcej: R. Grzeszczak, Rola parlamentów narodowych w procesie legislacji wspólnotowej jako strażników zasady pomocniczości, w: A. Dudzik (red.), op. cit. 
wania parlamentów narodowych o inicjatywie zmiany Traktatu Konstytucyjnego.

Postanowienia Traktatu precyzują i umacniają pozycję parlamentów narodowych $\mathrm{w}$ procesie integracji europejskiej. Jednocześnie wskazują one jednoznacznie na to, że wykorzystanie możliwości określonych przez Traktat zależeć będzie w pierwszym rzędzie od efektywności działania samych parlamentów narodowych i ich deputowanych oraz zakresu efektywności mechanizmu współpracy między parlamentem narodowym a rządem w ramach kompetencji własnej danego państwa członkowskiego.

Pomimo wspomnianych treści demokratycznych Traktat Konstytucyjny porządkując zasady, które obowiązują do dnia dzisiejszego, nie rozwiązuje problemu deficytu demokratycznego. Rozwiązania Traktatu nie likwidują problemu wyobcowania obywateli od europejskiego procesu politycznego.

Problemy z ratyfikacją Traktatu Konstytucyjnego oraz kryzys polityczny, który w związku z tym zaistniał potwierdziły w dużym stopniu, że ten Traktat nie znalazł uznania w oczach obywateli europejskich. Jednak warto pamiętać, że wpływ na zaistniałą sytuację miały również inne czynniki: w tym sytuacja społeczna i gospodarcza w państwach unijnych.

Pytaniem otwartym pozostaje - czy swoje ,jestem przeciwko" obywatele europejscy stawiali wobec samej konstytucji i jej treści, czy wobec całej złożonej sytuacji, w jakiej znalazła się dzisiaj Unia Europejska.

Dyskusja, której przedmiotem jest niedobór demokracji, obejmująca swym zasięgiem wiele zagadnień, jest wielowątkowa i wielopłaszczyznowa. W obecnej sytuacji można wysunąć wniosek, że deficyt demokratyczny Unii Europejskiej i sposoby jego rozwiązania na długo jeszcze pozostaną problemem otwartym.

\section{Summary}

The problem of democratic deficit in European institutions did not draw the particular attention of either EU officials or the national leaders of member states over the long period of the European Community's' existence. The political discussion over the issue of EU democratization was revived by a speech delivered by German minister of foreign affairs, Joschka Fisher, at the Humboldt University on May 12, 2000. Presenting his vision of the future of European integration this German politician emphasized that it was necessary to solve the 'problem of democracy' among others. Shortly before this, democratic deficit had become the subject of a comprehensive scientific analysis. The literature of the subject examined sources, formulated the definitions of democratic deficit, and searched for the answers to the question of what the European Union is, what democracy is and whether it is appropriate to talk about a democratic non-state. 